\title{
Cytokine Receptor-Like Factor 1
}

National Cancer Institute

\section{Source}

National Cancer Institute. Cytokine Receptor-Like Factor 1. NCI Thesaurus. Code C104952.

Cytokine receptor-like factor 1 ( $422 \mathrm{aa}, \sim 46 \mathrm{kDa}$ ) is encoded by the human CRLF1 gene. This protein may be involved in both immune function and nervous system development. 